\title{
Groundwater Chemistry and Overpressure Evidences in Cerro Prieto Geothermal Field
}

\author{
Ivan Morales-Arredondo, María Aurora Armienta, and Nuria Segovia \\ Instituto de Geofísica, Universidad Nacional Autonoma de Mexico, Cd. Universitaria, 04510 Mexico City, Mexico \\ Correspondence should be addressed to Ivan Morales-Arredondo; ivanma@geofisica.unam.mx
}

Received 19 May 2017; Revised 30 October 2017; Accepted 19 November 2017; Published 18 December 2017

Academic Editor: Ian Clark

Copyright (C) 2017 Ivan Morales-Arredondo et al. This is an open access article distributed under the Creative Commons Attribution License, which permits unrestricted use, distribution, and reproduction in any medium, provided the original work is properly cited.

In order to understand the geological and hydrogeological processes influencing the hydrogeochemical behavior of the Cerro Prieto Geothermal Field (CP) aquifer, Mexico, a characterization of the water samples collected from geothermal wells was carried out. Different hydrochemical diagrams were used to evaluate brine evolution of the aquifer. To determine pressure conditions at depth, a calculation was performed using hydrostatic and lithostatic properties from $\mathrm{CP}$, considering geological characteristics of the study area, and theoretical information about some basin environments. Groundwater shows hydrogeochemical and geological evidences of the diagenetic evolution that indicate overpressure conditions. Some physical, chemical, textural, and mineralogical properties reported in the lithological column from CP are explained understanding the evolutionary process of the sedimentary material that composes the aquifer.

Dedicated in memory of Dr. Ramiro Rodriguez C.

\section{Introduction}

Different authors have observed that the origin of some brines around the world can be caused by diagenesis evolution and porewater trapped during burial [1-3]. Commonly, porewater shows characteristics according to the depositional environment [4]. The different stages of diagenesis are composed of burial and compaction of material in sedimentary basins; the sandstones and shales undergo changes in their physical, chemical, textural, and mineralogical properties which are reflected in the sediment density, the compaction of the granular package, and loss of porosity [5]; additionally, a chemical alteration occurs in sandstones generating cementation and lithification as a product of chemical precipitation affecting detrital grains, dissolution, recrystallization, or mineralogical alteration [6]. Silica is the most abundant cementing agent in sandstones, compared to calcium carbonate, either calcite or aragonite, since the latter dissolves more easily in contact with groundwater, mainly the second [7]. In the diagenetic stages, interstitial fluids are constantly lost in most shales [8]; this phenomenon can occur at low depth and can last for thousands or hundreds of thousands of years or have a longer duration and greater depth; but when it suddenly occurs and the permeability of the medium is so low that it does not allow the interstitial fluid to leak, an increasing degree of stress can be generated [9]; this geological event is known as overpressure [10]. Overpressure is an abnormally high pressure in the subsoil that exceeds the hydrostatic pressure at a certain depth; this pressure is carried out in the pores where the pressure of the interstitial fluids increases as the overcoat increases $[11,12]$. Overpressure indicates that the high pressures developed during compaction do not dissipate efficiently [10] and can generate hydraulic fracturing in the system (stress applied to compressible rock and fluid expansion). These processes generate overpressured fluids related to porosity reduction, changes on porewater flow, and diagenetic reactions due to compaction and disequilibrium in a sedimentary basin [12-14]. Also overpressure can be related to chemical compaction due to changes in mineralogy (e.g., ion exchange, dissolution/precipitation) or to diagenetic processes and fluid expansion by thermal water in pore space. 

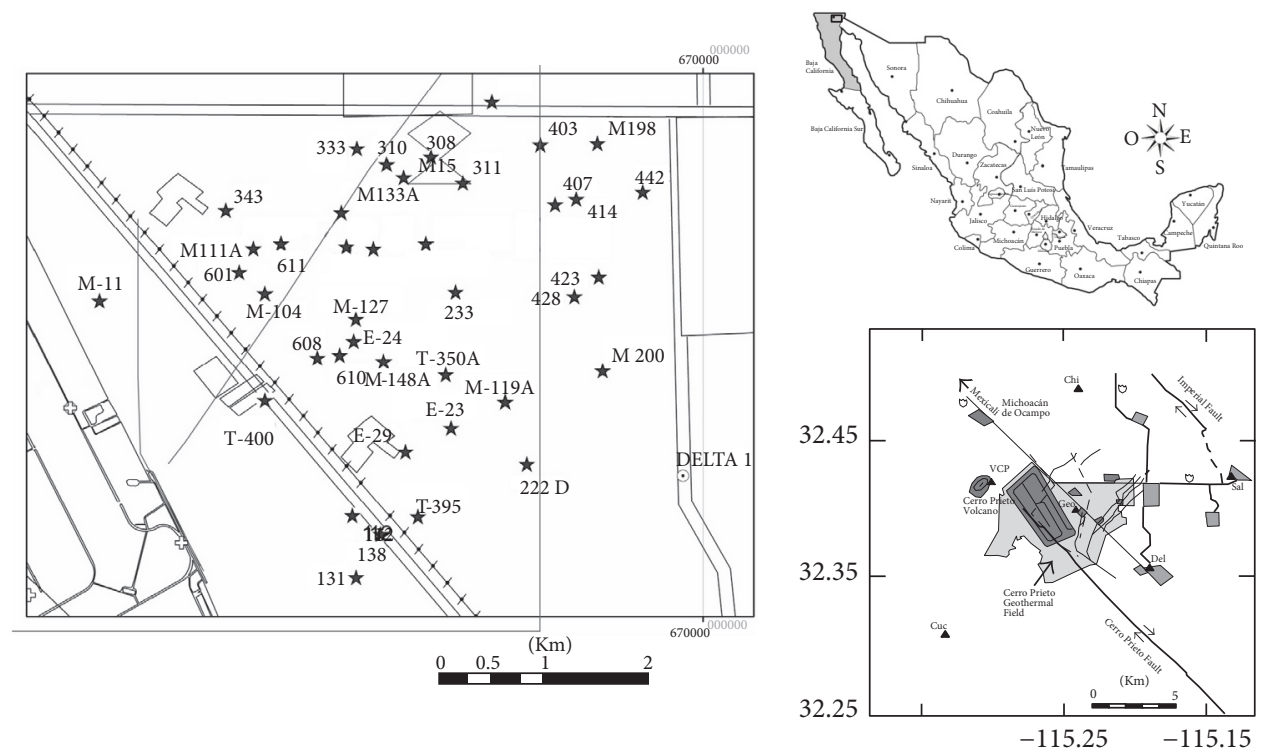

Figure 1: Localization of Cerro Prieto Geothermal Field and sampled wells.

Cerro Prieto Geothermal Field (CP), located in northwestern Mexico $\left(32^{\circ} 24^{\prime} 43^{\prime \prime} \mathrm{N}, 115^{\circ} 14^{\prime} 41^{\prime \prime} \mathrm{W}\right)$, is a brine with high-temperature geothermal system characteristics. Several studies about the origin and behavior of $\mathrm{CP}$ groundwater have been reported [15-18]. According to geological evidences, a large accumulation of sedimentary material from a continental and marine origin, overlying the depositional basin, is related to the origin of brine [17]. The sedimentary material shows diagenetic evolution evidences and porewater trapped between sediment grains during burial processes. The porewater is saline with high $\mathrm{Cl}^{-}, \mathrm{Na}^{+}, \mathrm{Ca}^{2+}$, and $\mathrm{K}^{+}$concentration; in geothermal brines this characteristic is common $[1,2$, 10]; the composition depends mainly on the primary origin, mineralogical composition of the sediments and their modification due to diagenetic processes (e.g., facies distribution), and hydrothermal characteristics $[15,19]$. Among the most evident diagenetic processes in $\mathrm{CP}$ are cementation, mineral replacement, recrystallization, authigenesis, and growth of concretions and nodules [16]. On the other hand, in deep sedimentary basins as $\mathrm{CP}$, mechanical processes of deformation related to burial mechanisms are common; likewise, hydrostatic and lithostatic conditions increase with depth due to an increase of the superposed fluids hydraulically connected, through the pore and the pressure exerted by sediments overload [10]. If pore pressure in deep aquifers like $\mathrm{CP}$ is higher than expected from hydrostatic conditions, anomalous pressure (overpressure) can be generated; overpressure is common mainly within $2-4.5 \mathrm{~km}$ depth [10-12].

According to geochemical evidences, the origin of geothermal brine at $\mathrm{CP}$ could be governed by mixing processes related to a hydrothermal environment and the sedimentary material located at depth which shows burial diagenesis evolution with hydrogeochemical evidences of an overpressurized environment. The aim of the present study was to evaluate hydrogeochemical behavior of geothermal groundwater and its relation with diagenetic processes, including overpressure.

\section{Localization}

Cerro Prieto Geothermal Field (CP), located in Mexicali Valley, SE of Mexicali City, in Baja California State, Mexico (Figure 1), is a Basin of Salton Sea [17]. Climate is arid with temperatures up to $40^{\circ} \mathrm{C}$ in July and to $4^{\circ} \mathrm{C}$ in winter. The average annual precipitation is $55 \mathrm{~mm} /$ year and the average annual evaporation is $2200 \mathrm{~mm}$ /year [23]. Groundwater at $\mathrm{CP}$ is extracted from geothermal wells that are in constant exploitation to generate electricity. The Comisión Federal de Electricidad of Mexico (CFE) operates and manages the Geothermal Field. CP power production is up to $720 \mathrm{MW}$ and is composed of five individual units: CP1, CP2, CP3, $\mathrm{CP} 4$, and CP5; each unit has a total capacity of production with a specific number of production wells. Sampled wells are indicated in Figure 1. Their localization in the five individual $\mathrm{CP}$ units is included in Table 1. All the wells are located in zone "beta," 1500 to $3100 \mathrm{~m}$ depth [17].

2.1. CP Geology. The lithology around CP is composed of gneiss (quartz-feldspars), shale (quartz-mica), marble, amphibolite, and quartzite from Permic to Jurassic [24] and metamorphic, granitic, and granodiorite rocks which are intruded by batholitic rocks [16], together with dacite and andesite from Miocene and rhyodacite from Quaternary [25]. The tectonic basin was filled by sedimentary material that, due to burial, compaction, and diagenesis processes, evolved to gray shales from Late Miocene (shales and silt shales that vary from light gray to black); this unit overlies the granitic basement and the mafic intrusive and is interlayered by permeable sandstones (composed of quartz and feldspars; arkoses type). The thickness is near $3000 \mathrm{~m}[21,26]$. Immediately above a layer of brown shale (shale and silt shale), 


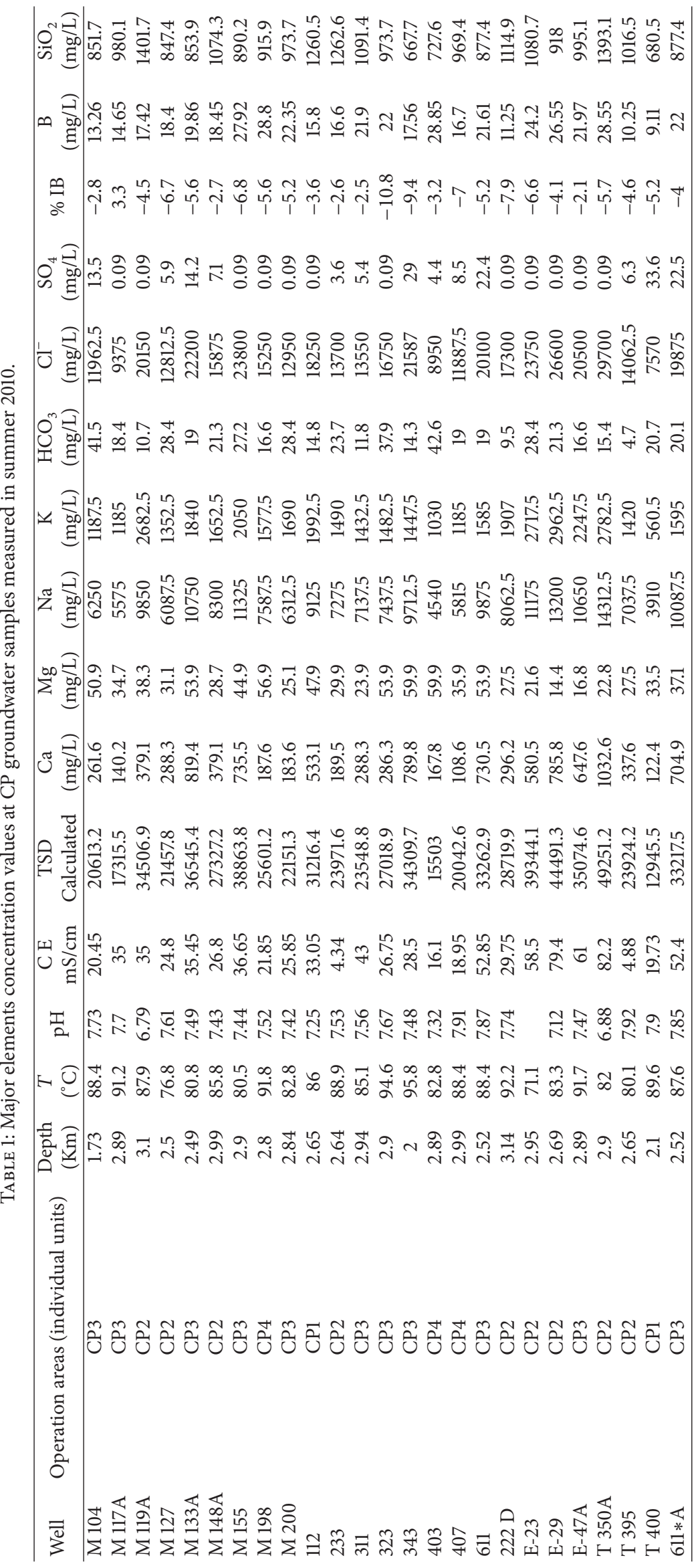


the gray shale covers interlayered permeable sandstones and sands cemented by carbonates, about $500 \mathrm{~m}$ thickness [21]. In these zones, a rapid distribution of geothermal fluids enhances the recharge. Erratic mudstone layer and unconsolidated clastic sediments (clays, silts, sand, and little gravel) overlie all the previous units. The thickness of these units is between 400 and $2500 \mathrm{~m}$ [26]. Sedimentary material shows evidence of the diagenetic evolution and recrystallization processes due to an incipient low grade metamorphism.

The geological evolution of $\mathrm{CP}$ is a complex blend of rifting, rapid deltaic sedimentation, and large scale strikeslip faulting located within the Salton Basin [16, 19, 21, 27]. The Geothermal Field is placed in a shear zone where NWSE and NE-SW fault systems intersect. The more important faults are Cucapá, Imperial, Cerro Prieto, and Michoacán [21]. This fault system is part of a major regional lineament that penetrates deep into the crustal and basement rocks and serves as conduit for geothermal flow. The system originates in a tectonic basin of $5200 \mathrm{~m}$ depth, filled by alluvial and deltaic sediments from Tertiary to Quaternary [21].

Vonder Haar and Howard [27] observed that, in sandstone and shale units, a mineral dissolution/precipitation took place along microfractures, originating secondary porosity and newly precipitated hydrothermal minerals, causing a reduction of permeability. Likewise, Elders et al. [20] observed cementation, mineral replacement, recrystallization, authigenesis, and growth of concretions and nodules; these processes are related to diagenesis.

2.2. CP Hydrogeology. Some authors consider that CP brine may have been formed from marine evaporite dissolved and partly by evaporated Colorado River water [16, 19, 21, 28-31]. However, according to geological evidences, a large accumulation of sedimentary material, overlying the depositional basin, from a continental and marine origin and mixing with meteoric water [30-33], was related to the origin of brine [17]. The sedimentary material shows diagenetic evolution evidences and porewater trapped between grains during burial processes. Isotopic evaluations $\left({ }^{18} \mathrm{O},{ }^{2} \mathrm{H}\right)$ and chemical analysis $\left(\mathrm{Cl}^{-}\right.$and $\left.\mathrm{Br}\right)$ elaborated by Coplen [34] and Birkle et al. [35] suggest that Salton Sea was the probable predecessor of high chlorinated groundwater of CP.

\section{Methodology}

A hydrogeological and hydrogeochemical study was carried out in geothermal groundwater samples from CP following standard methods of APHA-AWWA [38]. Water samples were collected from geothermal wells that are in constant exploitation. Temperature, $\mathrm{pH}$, and conductivity were measured in the field during the summer of 2010 and calibrated to the water temperature at each site. The chemical analyses for the major elements, $\mathrm{B}$ and $\mathrm{SiO}_{2}$, were performed at the Analytical Chemistry Laboratory of the Geophysics Institute, UNAM, Mexico (the laboratory participates in international calibration exercises of chemical analyzes of geothermal waters). Boron was determined by colorimetry through reactions with carminic acid (Method 4500-B C) APHAAWWA [38]. $\mathrm{SiO}_{2}$ was determined by atomic absorption spectrophotometry with flame and UV-visible spectroscopy (molybdosilicic acid method). Major ions were analyzed following standard methods [38]. $\mathrm{HCO}_{3}{ }^{-}$and $\mathrm{CO}_{3}{ }^{2-}$ were determined by volumetry (titrating with $\mathrm{HCl}$ ), $\mathrm{Ca}^{2+}$ and $\mathrm{Mg}^{2+}$ were determined by volumetry (titrating with EDTA), $\mathrm{Cl}^{-}$was determined by potentiometry with selective electrodes $\left(4500-\mathrm{Cl}^{-}\right)$[38], $\mathrm{Na}^{+}$and $\mathrm{K}^{+}$were determined by atomic emission spectrophotometry $\left(3500-\mathrm{Na}^{+}\right.$and $\left.\mathrm{K}^{+}\right)$, and $\mathrm{SO}_{4}{ }^{2-}$ was determined by turbidimetry $\left(4500-\mathrm{SO}_{4}{ }^{2-}\right)$. Analytical quality was assessed through ionic balance (less than $10 \%$ ) and the use of certified (NIST) reference solutions.

In order to evaluate brine evolution of $\mathrm{CP}$, different techniques were used: (a) Carpenter [39] evaluated the behavior of major elements using a plot with concentrations as a function of dissolved chloride concentration, considering the composition of seawater during evaporation and diagenesis; using chemical results of CP groundwater a similar evaluation was elaborated; (b) Davisson and Criss [40] devised a diagram to determine the geochemical evolution of mineralogy in brines applying an evaluation of $\mathrm{Na}_{\text {(deficit) }}$ and $\mathrm{Ca}_{\text {(excess) }}$ in water samples; hydrogeochemical results of samples from $\mathrm{CP}$ were evaluated with this diagram; (c) Boschetti [3] considers $\mathrm{B}-\mathrm{Cl}$ concentrations to explain the evolutionary process in the groundwater; $\mathrm{B}-\mathrm{Cl}$ diagram was used to determine the dominant geological environment in CP. A geochemical simulation with the measured water concentrations was carried out using the Phreeqc $\odot$ program to determine saturation indexes.

In order to determine pressure conditions, a calculation was performed using hydrostatic and lithostatic properties from $\mathrm{CP}$, considering geological characteristics of the study area and theoretical information about some basin environments. To estimate pressure conditions $\left(P_{l}(h)\right)$ exerted by a geological column at a depth $(h)$ offshore in a geologic formation, (1) was used [12]:

$$
P_{l}(h)=g \int_{0}^{h_{w}} \rho_{\text {sea }} d h+g \int_{h_{w}}^{h} \rho_{b} d h .
$$

It is necessary to take into account pure water column weight at sea level $h=0$, depth of seawater column $h_{w}$, seawater density $\rho_{\text {sea }}=1100 \mathrm{~kg} / \mathrm{m}^{3}$, gravity constant $g=9.78\left(\mathrm{~m} / \mathrm{s}^{2}\right)$, and material density (rock or sediments) $\rho_{b}$. The integral about overburden weight of sediments can be replaced by a sum of the individual weights of layers [12]:

$$
P_{l}(h)=g \int_{0}^{h_{w}} \rho_{\text {sea }} d h+g \sum_{i=1}^{n} d_{i}\left[\rho_{w} \varphi_{i}+\rho_{r i}\left(1-\varphi_{i}\right)\right],
$$

where it is important to consider the number of layers ( $n i$ ) with thickness $d_{i}$ ( $i$ is the layer number measured in $\mathrm{m}$ ), rocks density $\rho_{r i}\left(\mathrm{~km} / \mathrm{m}^{3}\right)$, porosity $\varphi_{i}$, and water density $\rho_{w}$ (which can change with salinity variation, while temperature and pressure dependence is relatively small or negligible).

To estimate pressure in a reservoir unit from $\mathrm{CP}$ it was considered that the study area is located onshore, few meters above seawater level; therefore the integral including the weight of seawater column is zero; the distinctive strata units, their thickness, and depth of each sampled well were 


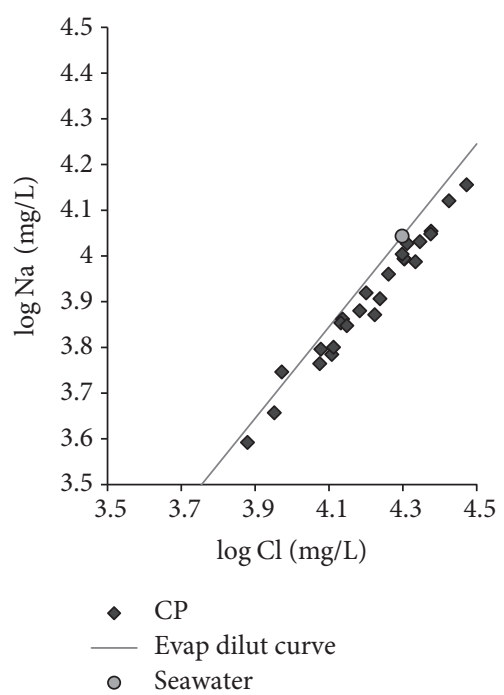

(a)

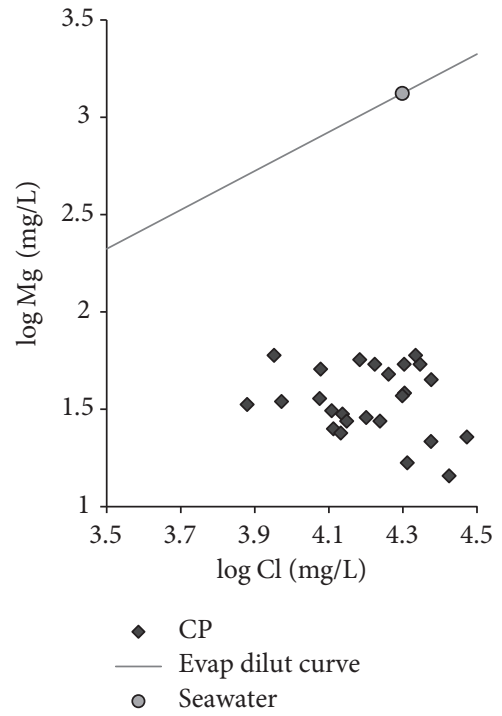

(d)

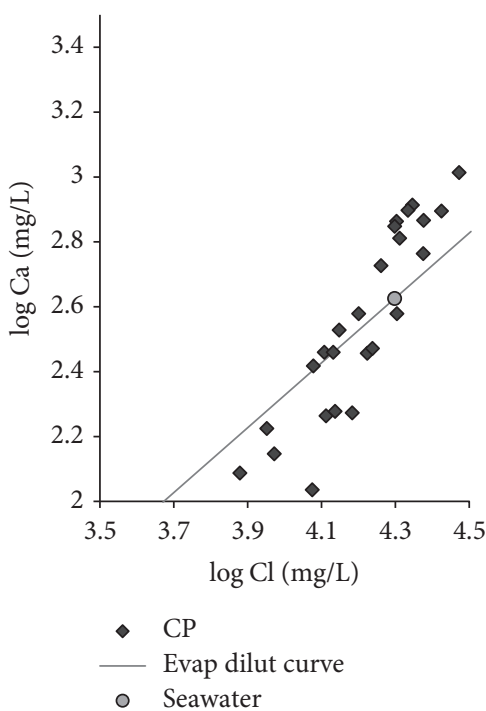

(b)

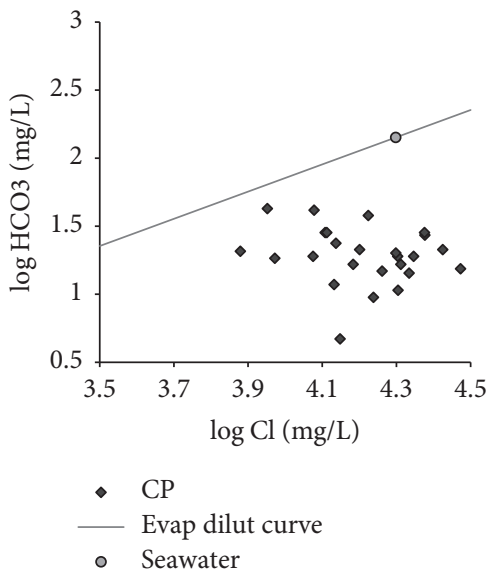

(e)

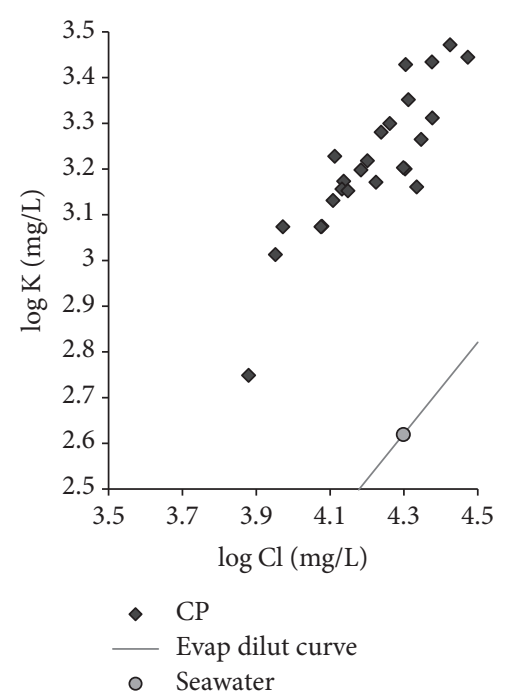

(c)

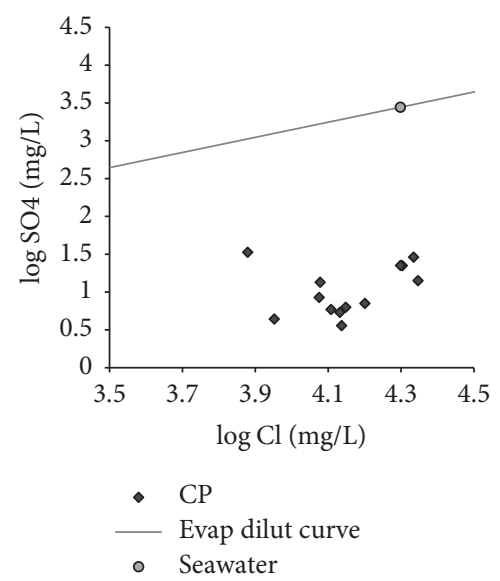

(f)

Figure 2: Variations in dissolved (a) $\mathrm{Na}^{+}$, (b) $\mathrm{Ca}^{2+}$, (c) $\mathrm{K}^{+}$, (d) $\mathrm{Mg}^{2+}$, (e) $\mathrm{HCO}_{3}{ }^{-}$, and (f) $\mathrm{SO}_{4}{ }^{2-}$ concentrations as a function of dissolved chloride concentration. The solid line on each plot is the seawater evaporation-dilution curve for each cation; circle is the ionic composition of seawater.

considered; the porosity values reported by Olson [41] and Hiriart Le Bert [42] in the geologic material from CP were used (between 0.15 and 0.25 ), for lithological units without reported porosity; theoretical values proposed by distinct authors studied unlike geological material and depth were used (e.g., mudstone and shales, slate, quartz, feldspars, uncemented sandstones, or sandstones as reservoirs) [43-46].

\section{Results and Discussion}

4.1. Major Elements in CP Groundwater. Table 1 shows the major solutes concentration in $\mathrm{CP}$ groundwater.

In Table 1 chemical results from the studied wells are shown. Total dissolved solids were calculated from conductivity measures showing values between 12945.5 and $49251.2 \mathrm{mg} / \mathrm{L}$. These values are comprised between saline water $(>1,000 \mathrm{mg} / \mathrm{L})$ and brine $(>35,000)$. All the sampled wells are located at beta reservoir [17, 47]. To explain geochemical variations in $\mathrm{CP}$ brine it is necessary to evaluate the composition and removal of solutes by salt precipitation according to diagrams proposed by Carpenter [39] where the circle represents the solute-chloride composition of normal seawater; the line represents the limit between evaporationdilution curves of seawater and freshwater (Figure 2).

Figure 2 shows that groundwater in $\mathrm{CP}$ is dominated by high concentrations of $\mathrm{Na}^{+}, \mathrm{K}^{+}, \mathrm{Ca}^{2+}$, and $\mathrm{Cl}^{-}$. When $\mathrm{Cl}^{-}$concentration increases $\mathrm{Na}^{+}, \mathrm{K}^{+}$, and $\mathrm{Ca}^{2+}$ concentrations also increase in ratios $1: 1,1: 1$, and $2: 1$, respectively 


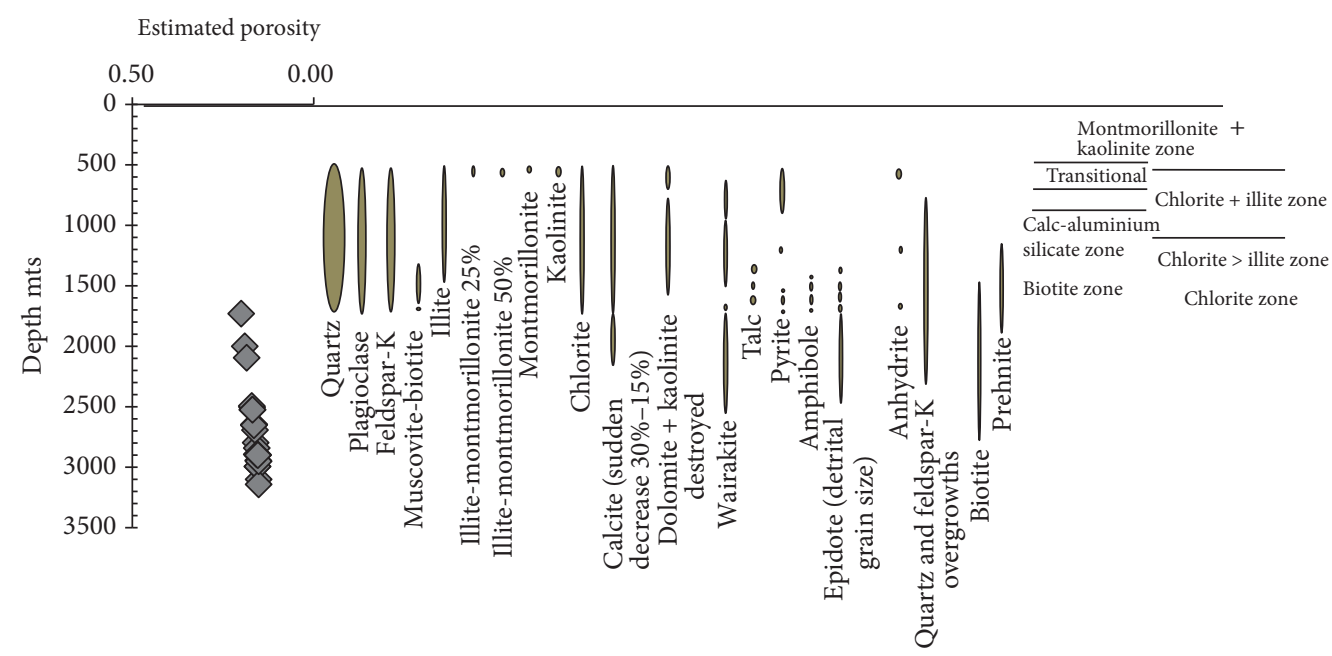

FIGURE 3: Mineralogy and paragenesis reported in lithology from CP, depth of sampled geothermal wells (modified by [20]), and estimated porosity considering geological characteristics.

(Figures 2(a), 2(b), and 2(c)). Bicarbonate ion, $\mathrm{Mg}^{2+}$, and $\mathrm{SO}_{4}{ }^{2-}$ have a low concentration (Figures $2(\mathrm{~d}), 2(\mathrm{e})$, and 2(f)), $\mathrm{Na}^{+}$values are parallel and near coincident with their respective evaporation-dilution curve (Figure $2(\mathrm{a})$ ), $\mathrm{Ca}^{2+}$ values cross the evaporation-dilution curve (Figure 2(b)), and $\mathrm{K}^{+}$ also increases with $\mathrm{Cl}^{-}$but the values are enlarged relative to the seawater evaporation-dilution curve (Figure 2(c)). In $\mathrm{CP}$ brine, $\mathrm{Mg}^{2+}$ concentrations lie well below the seawater evaporation trajectory indicating significant depletion of the element. According to Hanor [48] and Kharaka and Hanor [1] $\mathrm{Mg}^{2+}$ concentrations in brines decrease when temperature increases in the subsurface, and when alkalinity decreases [49]. Evaporation of continental waters has a more variable concentration range in water samples from $\mathrm{CP}$ due to evaporating mixtures of continental and marine water with meteoric water [50].

In CP brine depleted and enriched concentrations of some major elements are a consequence of reactions linked with the hydrothermal processes and water-rock interactions. Major elements concentrations are controlled by the alteration and formation of minerals like feldspar-K, plagioclases, quartz, biotite, amphibole, chlorite, pyrite, wairakite, prehnite, muscovite, epidote, and talc, as reported in CP by Elders et al. [20] and Izquierdo et al. [16] and shown by calculated saturation index values (Figures 3 and 4).

The $\mathrm{K}^{+}$origin is restrained by alteration of feldspar- $\mathrm{K}$, illite, and biotite and by muscovite formation. Very low $\mathrm{SO}_{4}{ }^{2-}$ and $\mathrm{HCO}_{3}{ }^{-}$concentrations in $\mathrm{CP}$ could be inhibited by the water interactions with anhydrite, dolomite, talc, pyrite, or calcite (Table 1; Figures 2 and 3); Elders et al. [20] report pyrite formation at depth. Low concentration of $\mathrm{Mg}^{2+}$ and high concentration of $\mathrm{Ca}^{2+}$ could be related to dolomitization of limestone as major source of $\mathrm{Ca}^{2+}$; and low $\mathrm{Mg}^{2+}$ contents are associated with the evolution of chlorites and micas when temperature and depth increase according to mineralogy reported in CP (Figure 3); similar behavior has been reported previously in hydrothermal brines with diagenetic evolution evidences [51] (Figure 3). Albite reactions at depth at high temperature can be linked with the slight $\mathrm{Na}^{+}$decrease $[16$, $30,31]$.

4.2. Saturation Index. Results of saturation index calculations are shown in Figure 4. From these results amorphous silica $\left(\mathrm{SiO}_{2} \mathrm{am}\right)$, albite, $\mathrm{k}$-feldspar, and in some cases k-mica show a behavior close to equilibrium with the fluid. Besides, quartz, chalcedony, talc, and crysocole are oversaturated. Dolomite, calcite, and aragonite are undersaturated at some sites and oversaturated at others, in agreement with Figures 2 and 3.

4.3. $N a_{(\text {deficit })}-C a_{(\text {excess })}$ Plot. Figure 5 was used to explain the initial composition of brines and the nature of fluidrock interactions. In the diagram, Basinal Fluid Line (BFL) is a straight line with a unit slope that indicates a $2 \mathrm{Na}$ $1 \mathrm{Ca}$ exchange relationship [40]; BFL represents the effect of plagioclase albitization on water composition. Seawater evaporation trajectory is a representation of the natural trends for seawater evaporation which is formed by large positive $\mathrm{Na}_{\text {(deficits) }}$ and small negative $\mathrm{Ca}_{\text {(excess) }}$; reactions involving seawater evaporation follow a vertical descent and afterwards produce large deficits along a horizontal trend. Halite dissolution in seawater or freshwater can produce negative values along a slope of $1: 4$.

To determine the origin and geochemical evolution of $\mathrm{CP}$ brine, an evaluation of $\mathrm{Na}_{\text {(deficit) }}$ and $\mathrm{Ca}_{\text {(excess) }}$ was applied to explain the initial composition and nature of fluid-rock interaction (Figure 5). All the analyzed water samples from $\mathrm{CP}$ were located right and over the seawater evaporation trajectory (SET) in the $\mathrm{Na}_{\text {(deficit) }}$ - $\mathrm{Ca}_{\text {(excess) }}$ diagram (Figure 5) indicating that the fluids are a product of brine that passed the point of halite precipitation evaporated (along of $\mathrm{Na}_{\text {(deficit) }}$ axis). The horizontal line of $\mathrm{CP}$ has a large positive $\mathrm{Na}_{\text {(deficit) }}$ and a small negative $\mathrm{Ca}_{(\text {excess) }}$, but the fluid is more enriched in $\mathrm{Ca}_{\text {(excess) }}$ than expected from seawater evaporation.

Dolomitization produces elevated Ca contents, increasing $\mathrm{Ca}_{\text {(excess) }}$ without changing the $\mathrm{Na}_{\text {(deficit) }}$, and can explain 

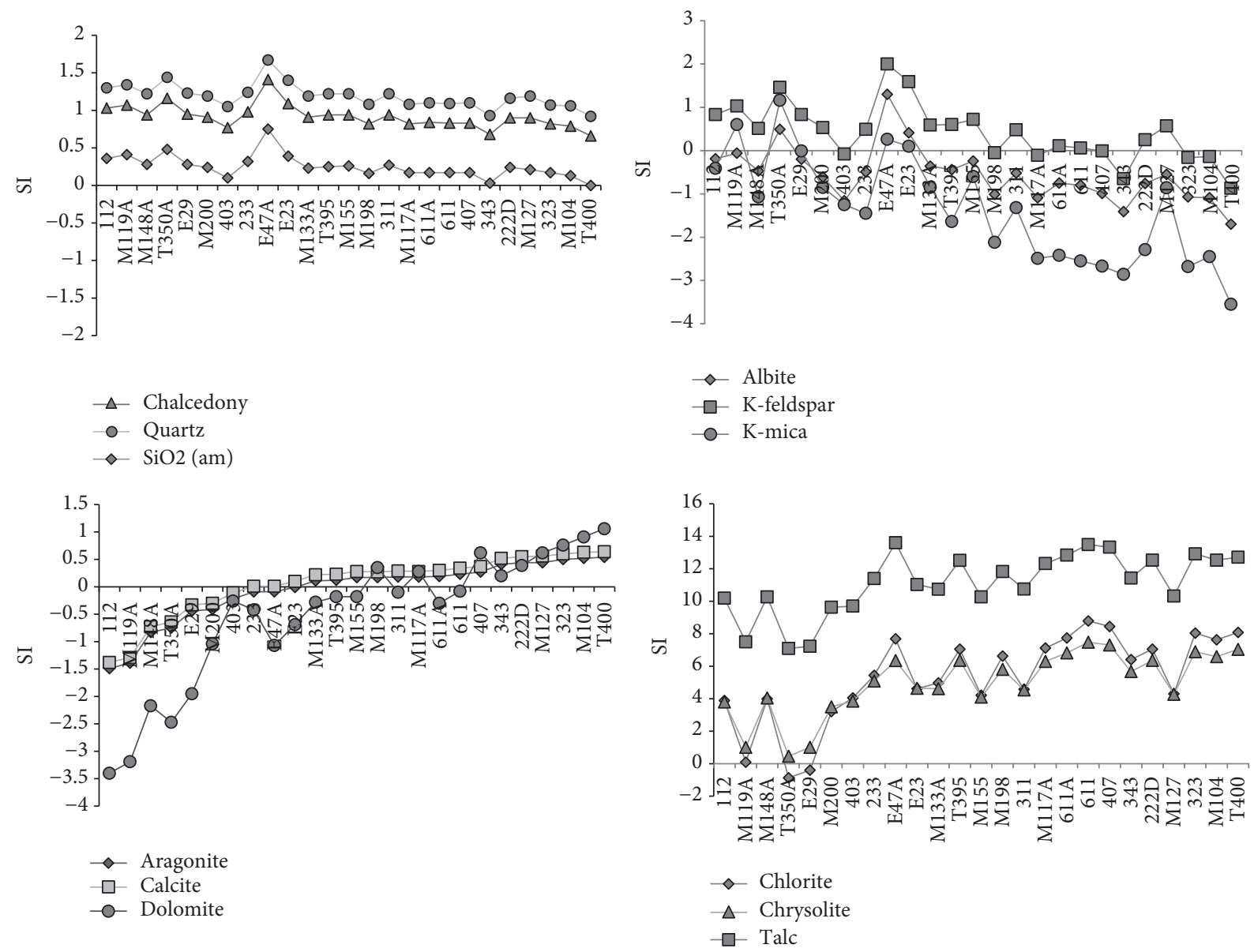

FIgURE 4: Saturation index diagrams.

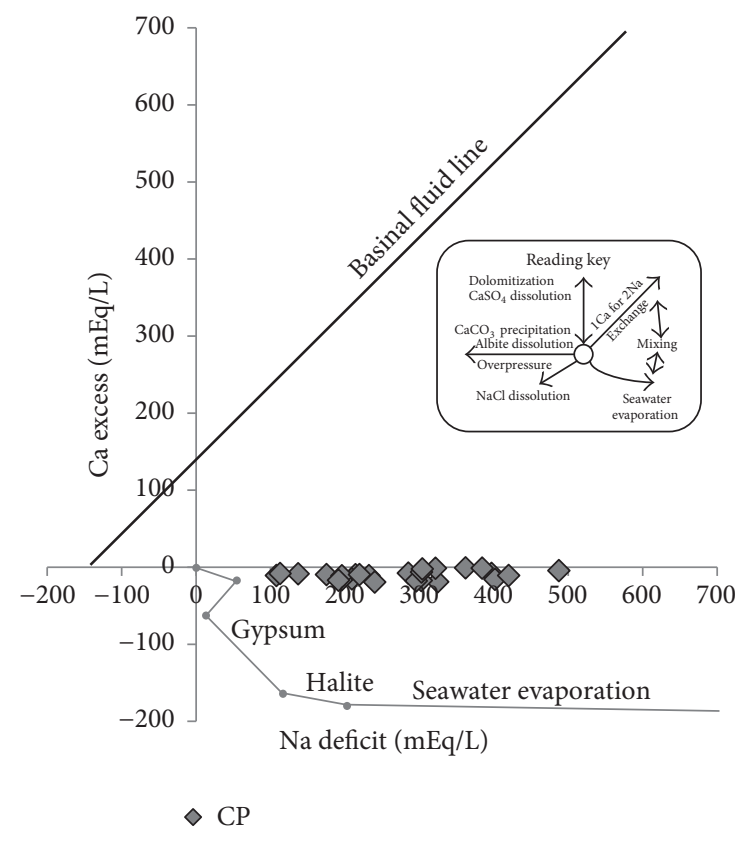

FiguRE 5: Diagram $\mathrm{Na}_{\text {(deficit) }}$ and $\mathrm{Ca}_{\text {(excess) }}$. Diamonds correspond to the CP sampled wells. the phenomenon observed in CP. Other dissolved minerals could interact in the evolutionary processes to brine aside from the above-mentioned ones, such as calcite, anhydrite, quartz, halite, and illitization to smectite transformation. Often, these geochemical processes are treated separately but in some situations the origin is linked to a mixing of processes and is not mutually exclusive [1]. Illite formation involves reactions relevant for diagenesis: (a) release of water during transformation of feldspar to kaolinite and smectite; (b) potassium and silica budget $[2,52]$. Some of these processes can occur in CP.

Geology of CP shows equilibrium with clays (Figure 4); groundwater shows high concentrations of $\mathrm{K}^{+}$. Also reactions between calcite, illite, and $\mathrm{K}^{+}$to form $\mathrm{K}$-feldspar could be involved in brine evolution. According to the results (Figures 2 and 5) the origin of CP groundwater is a consequence of an evolution of dissolved evaporative products (e.g., halite), residual water remaining during the dissolution precipitation of seawater evaporites, and different water-rock interactions (e.g., clays, siltstones, and shales) but could have a slight contribution to exchange reactions $1 \mathrm{Ca}$ for $2 \mathrm{Na}$ in the aquifer by albitization of plagioclases, which could change the ionic composition of fluids (Figure 5), according to the following 


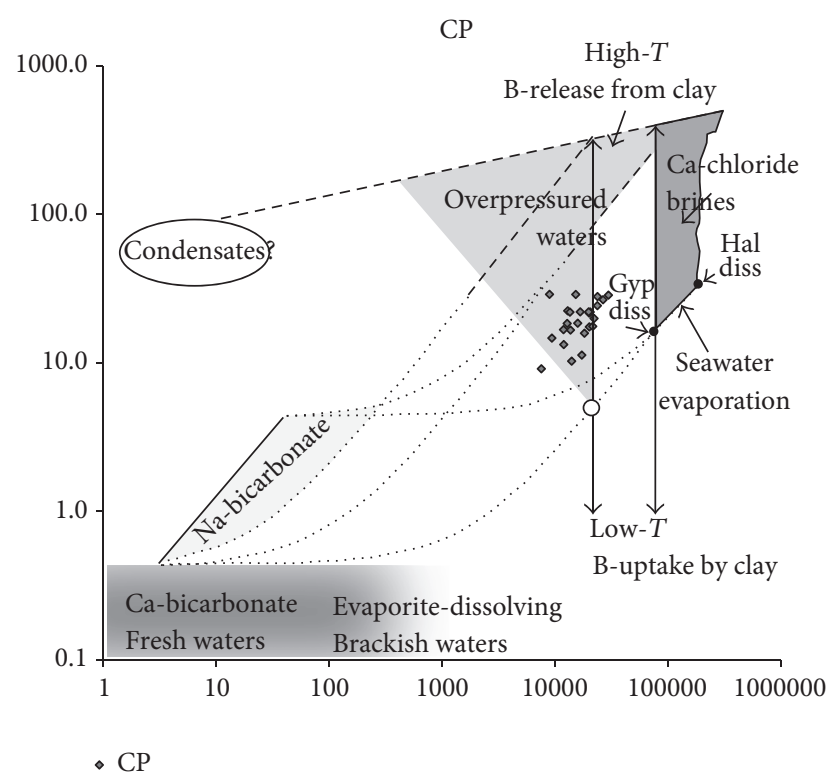

FIGURE 6: CP overpressure: chloride versus boron concentration (mg/L; fields and paths from [3]). Dashed lines represent binary mixings where specific geological environments dominate. Diamonds correspond to the $\mathrm{CP}$ sampled wells.

reaction proposed by Carpenter [39], Hanor [48], and Demir and Seyler [53]:

$$
\begin{gathered}
\mathrm{CaAl}_{2} \mathrm{Si}_{2} \mathrm{O}_{8(\mathrm{an})}+4 \mathrm{SiO}_{2(\mathrm{aq})}+2 \mathrm{Na}^{+} \\
=2 \mathrm{NaAlSi}_{3} \mathrm{O}_{8(\mathrm{ab})}+\mathrm{Ca}^{2+} .
\end{gathered}
$$

\subsection{Overpressure}

4.4.1. B-Cl Plot. Some hydrogeochemical evidences (Figures 2 and 5) shown in a B-Cl plot (Figure 6) indicate that overpressurized fluids participate in the evolutionary process of the $\mathrm{CP}$ geothermal brine. Boron behavior helps to define these geologic environments because B is adsorbed by clay minerals and is released into the fluid in a deep environment, mainly when tectonic stresses by vertical and/or lateral compaction are high and temperature increases with depth, and stronger geologic deformations are generated $[10,12,54]$.

\subsubsection{Pressure Conditions Estimated due to Overburden.}

Some authors $[55,56]$ estimated pressure at depth at CP considering the host rock density at a specific depth. The obtained values were in the range between 0.5 and $42 \mathrm{MPa}$. Those calculations considered only geothermal water conditions from the extraction zone and no lithologic information was used from the stratigraphic columns of each site. To confirm hydrogeochemical evidence of overpressure, a calculation to determine pressure conditions was performed using hydrostatic and lithostatic properties from $\mathrm{CP}$ and theoretical information about some basin environments (Figure 7). It is necessary to consider that normal pressure increases with depth according to the hydrostatic pressure gradient $(10 \mathrm{MPa} / \mathrm{Km})$, higher or lower values of this gradient, and their associated depths are considered abnormal pressures (e.g., overpressure). Lithostatic pressure is equivalent to the total charge of the overlaying sediments in a geological formation and increases according to the lithostatic pressure gradient $(23 \mathrm{MPa} / \mathrm{Km})$ [10-12, 57].

In general, overpressured systems can take place when porewater is not expelled from rock at a proper rate, remaining under hydrostatic pressure. Overpressured volume rock must be trapped by low permeability layers where fluids move slowly, even when there is high pressure in the environment. The overpressure affects the effective stress that acts between the grains within the rock and generates a change in the compaction. In many areas of active sedimentation rate around the world, porewater pressure in deep groundwater $(>1 \mathrm{~km})$ is higher than would be expected from hydrostatic circumstances [10,57-59]. It is necessary to consider thermal expansion in the pore space (increasing volume) and increment of the system temperature by thermal conditions and by fluid movement and mineral phases transition [11]. According to Swarbrick et al. [11] and Kauerauf and Hantschel [12] secondary overpressure by chemical cementation may occur at large depths when porosity is reduced by dissolutiondiffusive transport-precipitation of silica cement (temperature affects diffusion-precipitation rate) or by fluid expansion processes when gas or thermal solutions are originated in highly permeable facies interconnected locally at certain depth levels generating compaction, rearrangement of grains, and reduction in the pore space. Some of these conditions could occur in CP aquifer [22].

The results obtained confirm that in $\mathrm{CP}$ overpressure is present (Figures 7 and 8). Positive anomalies with an increase of depth are shown between 0.6 and $3.1 \mathrm{~km}$; this phenomenon can be caused by a hydraulic seal. Overpressure coincides with lithology variation in CP [22], when sedimentary material composed of sand and clay changes to shale and sandstone due to clay and sand diagenesis and shale compaction (Figure 7). In CP, sandstone is hosted by a low permeability layer of shale and siltstones creating adequate conditions for this process. Overpressure in CP brine could occur as a consequence of a rapid sedimentation, deposition, and accumulation rates of fine-grained material along time and due to the stress increase in sediments, compressibility, or expansion of fluids by hydrothermalism.

Geological evidence in CP indicates that mineralogical changes occur at depth, mainly by diagenetic processes (Figure 5). According to the geochemical behavior observed in $\mathrm{CP}$, it is possible that mineral dissolution precipitation processes generated this phenomenon; osmosis, buoyancy, and tectonic or magmatic process can generate changes in mineralogy (e.g., feldspar to illite or smectite to illite conversion), diagenesis, and carbonate or silicate cementation. In $\mathrm{CP}$, sandstones and shales units reveal clogging, mineral dissolution, and mineral precipitation along microfractures as indicated by Vonder Haar and Howard [27]. In the study area the calcite dissolution and/or cementation more likely develops where cold water interacts with hotter rocks or precipitation of quartz and $\mathrm{k}$-feldspar occurs when hot waters interact with colder rocks $[16,20]$. Exchange of $\mathrm{Na}^{+}$by $\mathrm{K}^{+}$with a higher ion radius is carried out in mineral transformations and increases 

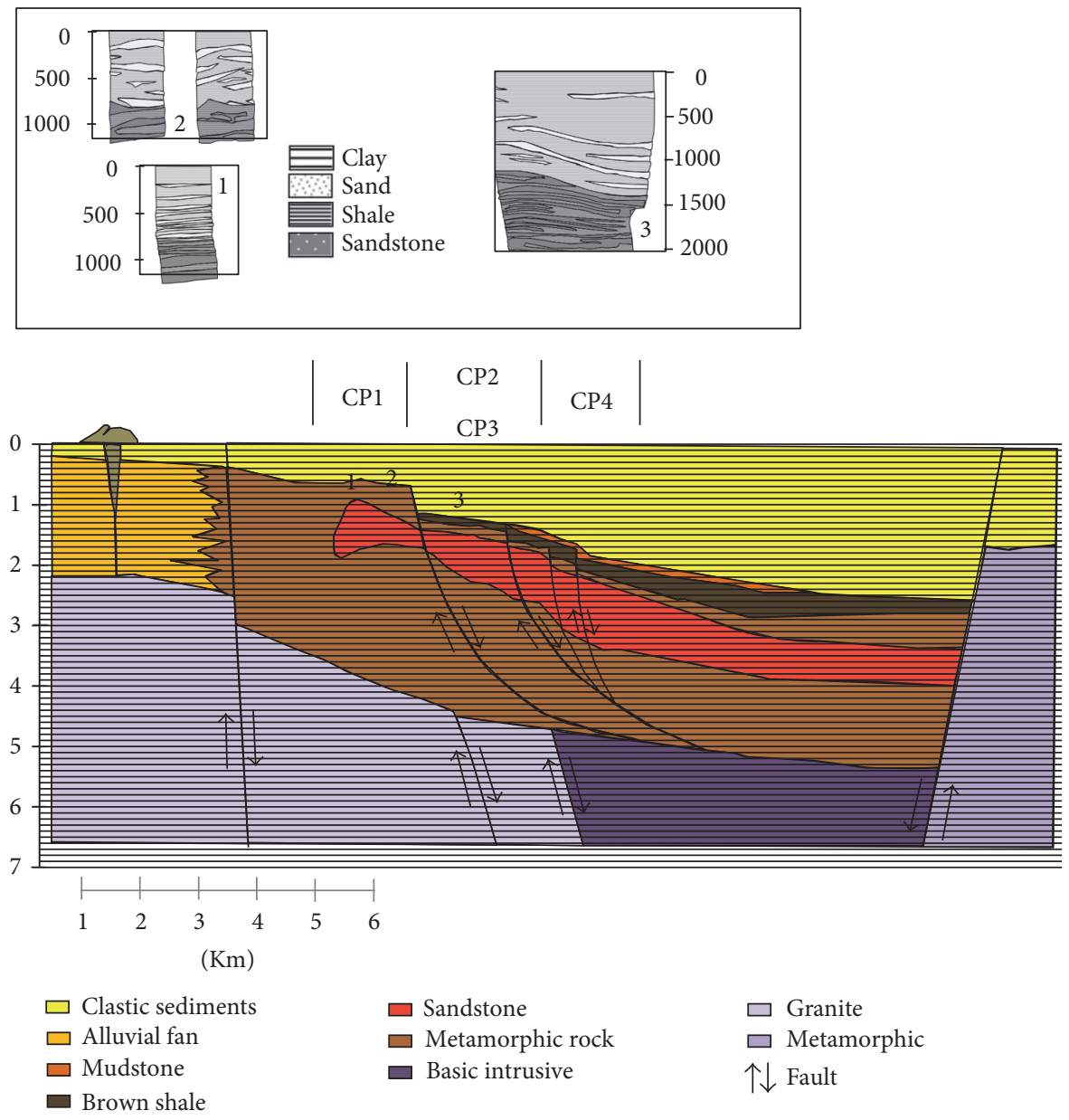

FIGURE 7: CP geology cross section. Stratigraphic column was modified from Lira [21] and Peña et al. [22].

the volume of the solid matrix [12]; this process is controlled by temperature and $\mathrm{K}^{+}$availability in minerals.

The permeability of sandstones in $\mathrm{CP}$ facilitates reactions between rocks and hydrothermal fluids (e.g., dissolution of some minerals); these reactions can reduce or increase the porosity and also generate secondary fracturing or microfracturing and modify physical properties [16, 21], which could cause overpressure (Figures 7 and 8). Sandy shale and siltstone facies in $\mathrm{CP}$ are most amenable to increased microfracturing. In sandstones (where high temperature dominates) and shales from $\mathrm{CP}$, mineral dissolution precipitation takes place along microfractures, which originates secondary porosity and newly precipitated hydrothermal minerals, causing a reduction of permeability.

\section{Geothermometry}

Alkali feldspar geothermometers are the most used tool to determine chemical equilibrium in fluids at depth in a geothermal system [60]. Na/K and $\mathrm{Na}-\mathrm{K}-\mathrm{Ca}$ geothermometers were developed to evaluate the temperature in high enthalpy geothermal systems [61]; these geothermometers are less affected by chemical reequilibration in mixing zones, but the calculated temperature may be affected by mixing with cold water or by deposition of aluminum-rich minerals or clays [62]. $\mathrm{Na} / \mathrm{K}$ geothermometers are adapted for temperatures between 180 and $350^{\circ} \mathrm{C} . \mathrm{Na} / \mathrm{K}$ geothermometers have been generally used to estimate temperatures at $\mathrm{CP}$ $[36,37,62]$. We applied (4) and (5) $[61,62]$ to evaluate the temperature of CP reservoir:

$$
\begin{aligned}
& T=\left(\frac{1178}{(1.47+\log (\mathrm{Na} / \mathrm{K}))}\right)-273.15 \\
& T=\left(\frac{1289}{(1.615+\log (\mathrm{Na} / \mathrm{K}))}\right)-273.15 .
\end{aligned}
$$

The temperature range of $\mathrm{CP}$ reservoir, calculated with $\mathrm{Na} / \mathrm{K}$ geothermometer, varies between 236 and $306^{\circ} \mathrm{C}$ for (4) and between 251 and $318^{\circ} \mathrm{C}$ for (5) (Table 2).

\section{Conclusions}

$\mathrm{CP}$ shows intermediate brine characteristics $(\mathrm{Na}-\mathrm{Ca}-\mathrm{Cl})$ with high $\mathrm{K}^{+}, \mathrm{Ca}^{2+}$, and salinity contents; the relation $\mathrm{Na}^{+} / \mathrm{Cl}^{-}$is less than 1 .

The porewater composition in $\mathrm{CP}$ evolved from its primary origin and was modified by the interaction with 

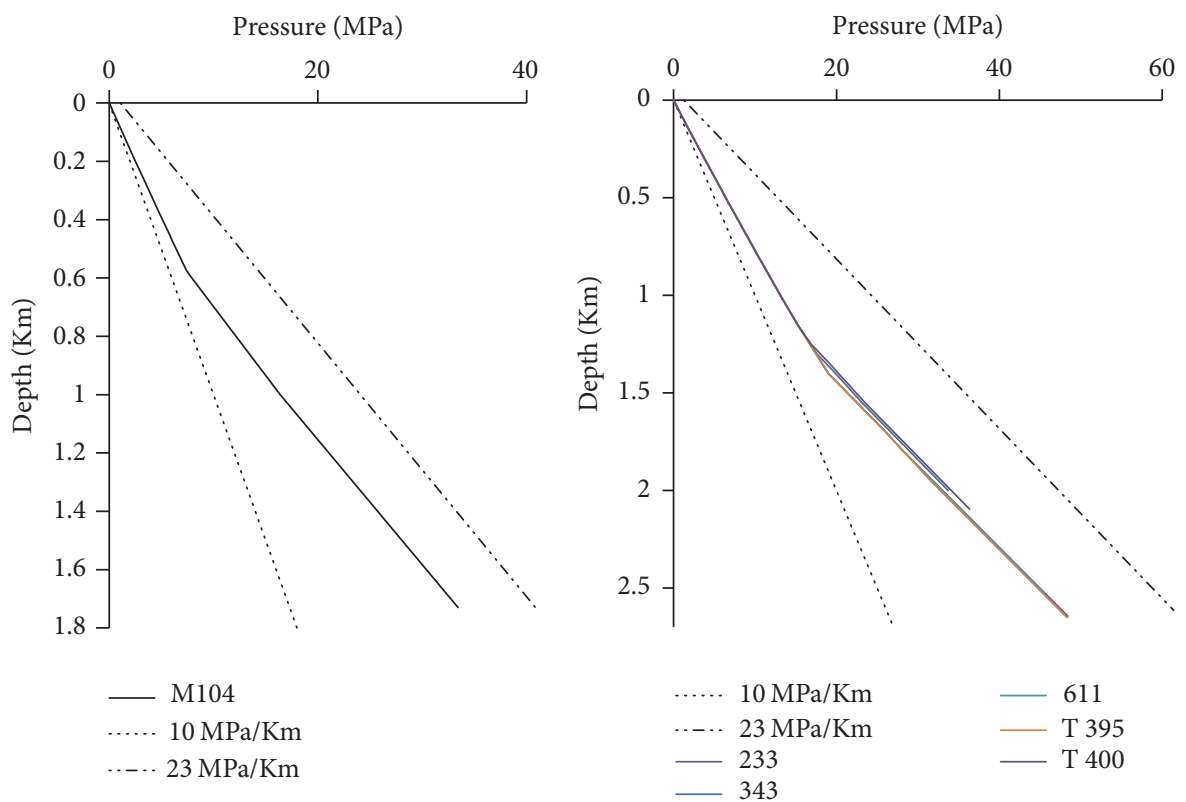

(a)

(b)

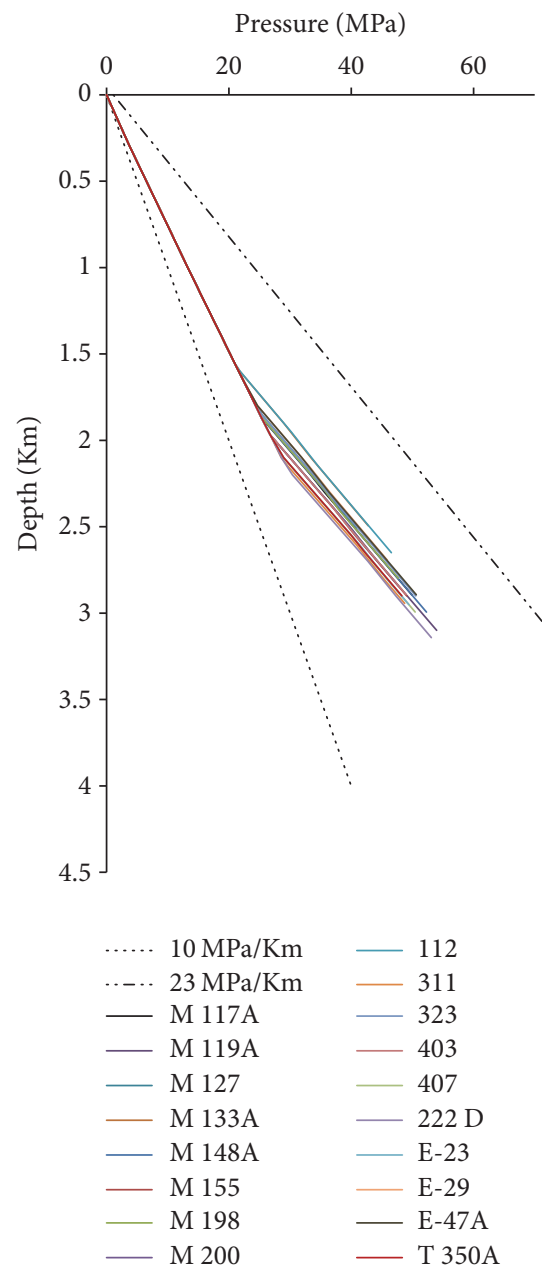

(c)

FIGURE 8: Plots represent pressure estimated conditions at depth: pressure conditions were calculated with the following values: porewater density $\rho_{w}=1040 \mathrm{~kg} / \mathrm{m}^{3}$, shale and mudstone density $\rho_{\text {sh }}=2700 \mathrm{~kg} / \mathrm{m} 3$, sandstone density $\rho_{\text {sd }}=2720 \mathrm{~kg} / \mathrm{m}^{3}$, slate density $\rho_{\mathrm{sl}}=2750 \mathrm{~kg} / \mathrm{m}^{3}$, and sedimentary material density $\rho_{\mathrm{sm}}=1650 \mathrm{~kg} / \mathrm{m}^{3}[10,12]$. 
TABLE 2: Results of $\mathrm{Na} / \mathrm{K}$ geothermometers.

\begin{tabular}{|c|c|c|c|c|c|c|c|c|}
\hline Well & $\begin{array}{c}{ }^{\circ} \mathrm{C} \mathrm{Na} / \mathrm{K} \\
{[36]}\end{array}$ & $\begin{array}{c}T{ }^{\circ} \mathrm{C} \mathrm{Na} / \mathrm{K} \\
{[37]}\end{array}$ & Well & $\begin{array}{c}{ }^{\circ} \mathrm{C} \mathrm{Na} / \mathrm{K} \\
{[36]}\end{array}$ & $\begin{array}{c}T{ }^{\circ} \mathrm{C} \mathrm{Na} / \mathrm{K} \\
{[37]}\end{array}$ & Well & $\begin{array}{c}T^{\circ} \mathrm{C} \mathrm{Na} / \mathrm{K} \\
{[36]}\end{array}$ & $\begin{array}{c}T^{\circ} \mathrm{C} \mathrm{Na} / \mathrm{K} \\
{[37]}\end{array}$ \\
\hline M 104 & 264 & 279 & 112 & 280 & 293 & $222 \mathrm{D}$ & 289 & 302 \\
\hline M 117A & 277 & 290 & 233 & 273 & 286 & E-23 & 292 & 305 \\
\hline M 119A & 306 & 318 & 311 & 270 & 284 & E-29 & 283 & 296 \\
\hline M 127 & 282 & 295 & 323 & 270 & 284 & E-47A & 276 & 290 \\
\hline M 133A & 254 & 268 & 343 & 240 & 255 & T $350 \mathrm{~A}$ & 267 & 281 \\
\hline M 148A & 269 & 283 & 403 & 284 & 297 & Т 395 & 271 & 285 \\
\hline M 155 & 259 & 274 & 407 & 272 & 286 & T 400 & 236 & 251 \\
\hline M 198 & 274 & 288 & 611 & 247 & 262 & $611 * \mathrm{~A}$ & 246 & 260 \\
\hline M 200 & 304 & 316 & & & & & & \\
\hline
\end{tabular}

minerals of the sedimentary material. Brine characteristics were acquired by deep-burial diagenesis processes and low grade metamorphism at high temperatures. Results show geochemical evidence of overpressured fluids due to compaction.

Groundwater samples from CP show a mixing of marine and continental water; this situation is partially related to a continental and evaporative precursor. The hydrogeochemical evidence indicates that the sedimentary material has porewater between grains, which was trapped during burial processes. The diagenetic processes could have generated high concentrations of $\mathrm{Cl}^{-}, \mathrm{Na}^{+}, \mathrm{K}^{+}$, and $\mathrm{Ca}^{2+}$. Calcium enrichment, $\mathrm{Na}^{+}$depletion, and $\mathrm{K}^{+}$release could have a relation with a contribution of exchange reactions $1 \mathrm{Ca}$ for $2 \mathrm{Na}$ in the aquifer by albitization of plagioclases or by illitization processes, respectively, and precipitation of secondary minerals. High $\mathrm{K}^{+}$and low $\mathrm{Mg}^{2+}$ contents are related to alteration of feldspar-K, illite, biotite, and muscovite formation. Ca-Na exchange with plagioclases could be a geochemical control on the fluids of $\mathrm{CP}$ and may directly explain slight $\mathrm{Ca}_{(\text {excess) }}$ and $\mathrm{Na}_{\text {(deficit) }}$ in the brine.

Overpressure in CP is related to burial mechanisms; secondary overpressure is related to chemical pressure by mineralogical changes and by fluid expansion, which increases with depth. The magnitude of overpressure may be produced by some characteristics of deposit formation (burial), permeability evolution of sedimentary material, and the compressibility of rock and fluid. Secondary overpressure in the system related to chemical pressure and porosity changes due to mineral dissolution can be generated at large depths. Fluid expansion takes place in the reservoir which generates compaction, rearrangement of grains, and reduction of pore space. Boron release at overpressure conditions can be related to high contents of $\mathrm{K}^{+}$in water.

\section{Conflicts of Interest}

The authors declare that they have no conflicts of interest.

\section{Acknowledgments}

The authors thank Aguayo A., Ceniceros N., and Cruz O. for chemical determinations. The authors acknowledge
Comision Federal de Electricidad for support on sampling within the Cerro Prieto Geothermal Field.

\section{References}

[1] Y. K. Kharaka and J. S. Hanor, "Deep Fluids in the Continents: I. Sedimentary Basins," Treatise on Geochemistry, vol. 5-9, pp. $1-48,2003$.

[2] T. Boschetti, L. Toscani, O. Shouakar-Stash et al., "Salt Waters of the Northern Apennine Foredeep Basin (Italy): Origin and Evolution," Aquatic Geochemistry, vol. 17, no. 1, pp. 71-108, 2011.

[3] T. Boschetti, "Application of brine differentiation and LangelierLudwig plots to fresh-to-brine waters from sedimentary basins: Diagnostic potentials and limits," Journal of Geochemical Exploration, vol. 108, no. 2, pp. 126-130, 2011.

[4] A. Arche, "Sedimentología del proceso físico a la cuenca sedimentaria," in Consejo Superior de Investigaciones Científicas, 978-84-00-09145-3, pp. 1-1273, Madrid, Spain.

[5] S. J. Blott and K. Pye, "Particle shape: A review and new methods of characterization and classification," Sedimentology, vol. 55, no. 1, pp. 31-63, 2008.

[6] A. Ceriani, A. Di Giulio, R. H. Goldstein, and C. Rossi, "Diagenesis associated with cooling during burial: An examplefrom Lower Cretaceous reservoir sandstones (Sirt basin, Libya)," AAPG Bulletin, vol. 86, no. 9, pp. 1573-1591, 2002.

[7] F. W. Witkowski, D. J. Blundell, P. Gutteridge, A. D. Horbury, N. H. Oxtoby, and H. Qing, "Video cathodoluminescence microscopy of diagenetic cements and its applications," Marine and Petroleum Geology, vol. 17, no. 10, pp. 1085-1093, 2000.

[8] C. H. Moore, "Carbonate reservoirs. Porosity evolution and diagenesis in a sequence stratigraphic framework," Developments in Sedimentology, vol. 55, 2001.

[9] M. S. Fantle, K. M. Maher, and D. J. Depaolo, "Isotopic approaches for quantifying the rates of marine burial diagenesis," Reviews of Geophysics, vol. 48, no. 3, Article ID RG3002, 2010.

[10] K. M. Hiscock and V. F. Bense, Hydrogeology Principles And Practice, Wiley Blackwell, 2nd edition, 2014.

[11] R. E. Swarbrick, M. J. Osborne, and G. S. Yardley, "Comparison of overpressure magnitude resulting from the main generating mechanisms," in Pressure Regimes in Sedimentary Basins and Their Prediction, A. R. Huffman and G. L. Bowers, Eds., vol. 76, pp. 1-12, American Association of Petroleum Geologists Memoir, 2002. 
[12] A. I. Kauerauf and T. Hantschel, Fundamentals of Basin and Petroleum Systems Modeling, Springer Science \& Business Media, 2009.

[13] O. Walderhaug, P. A. Bjørkum, P. H. Nadeau, and O. Langnes, "Quantitative modelling of basin subsidence caused by temperature-driven silica dissolution and reprecipitation," Petroleum Geoscience, vol. 7, no. 2, pp. 107-113, 2001.

[14] A. Zanella, P. R. Cobbold, and C. Le Carlier de Veslud, "Physical modelling of chemical compaction, overpressure development, hydraulic fracturing and thrust detachments in organic-rich source rock," Marine and Petroleum Geology, vol. 55, pp. 262274, 2014.

[15] E. Portugal and M. P. Verma, "Hidroquímica de la laguna de evaporación en Cerro Prieto," in Ingeniería hidráulica en México, vol. 16, pp. 153-174, Baja California, Mexico, 2 edition, 2001.

[16] G. Izquierdo, A. Aragón, E. Portugal, V. M. Arellano, J. de León, and J. Álvarez, "Mineralogía de la zona mineralizada de síliceepidota (ZMSE) del yacimiento geotérmico de Cerro Prieto B.C México," Geotermia, vol. 19, no. 2, pp. 2-12, 2006.

[17] V. M. Arellano, R. M. Barragán, A. Aragón, M. H. Rodríguez, and A. Pérez, "The Cerro Prieto IV (Mexico) geothermal reservoir: Pre-exploitation thermodynamic conditions and main processes related to exploitation (2000-2005)," Geothermics, vol. 40, no. 3, pp. 190-198, 2011.

[18] M. A. Armienta, R. Rodríguez, N. Ceniceros et al., "Groundwater quality and geothermal energy. The case of Cerro Prieto Geothermal Field, México," Journal of Renewable Energy, vol. 63, pp. 236-254, 2014.

[19] J. M. Camacho-Hernández, “Zonas de alteración hidrotermal y condiciones actuales del yacimiento: un enfoque para determinar zonas productoras al oriente del campo geotérmico de Cerro Prieto, BC," Geotermia. Revista Mexicana de Geoenergia, vol. 22, no. 2, pp. 35-45, 2009.

[20] W. A. Elders, J. R. Hoagland, S. D. McDowell, and J. M. Cobo, "Hydrothermal mineral zones in the geothermal reservoir of Cerro Prieto," Geothermics, vol. 8, no. 3-4, pp. 201-209, 1979.

[21] H. H. Lira, "Actualización del modelo geológico conceptual del yacimiento geotérmico de Cerro Prieto, BC," Geotermia, vol. 18, no. 1, pp. 37-46, 2005.

[22] A. L. Peña, C. I. Puente, and C. E. Díaz, "Modelo geológico del campo geotérmico de Cerro Prieto. Geothermal-Energy," Comision Federal de Electricidad, pp. 29-52, 1979, https://www.geothermal-energy.org/pdf/IGAstandard/DOE-CFE/1979/Pena .pdf.

[23] E. Portugal, J. Álvarez, and B. I. Romero, "Hydrochemical and isotopical tracers in the lacustrine aquifer of the Cerro Prieto area, Baja California, México," Journal of Geochemical Exploration, vol. 88, no. 1-3, pp. 139-143, 2006.

[24] M. Siem, The structure and petrology of Sierra El Mayor [Master, thesis], University of San Diego State, Northeastern Baja Calfornia, Mexico, 1992.

[25] A. L. Quintanilla-Montoya and F. Suárez-Vidal, "Cerro Prieto and its relation to the Gulf of California spreading centers," Ciencias Marinas, vol. 22, no. 1, pp. 91-110, 1996.

[26] R. J. M. Cobo, Configuración de los cuerpos litológicos de lodolita, lutita café, lutita gris, zonas de sílice y epidota, y sus relaciones con la tectónica del campo geotérmico de Cerro Prieto. Proceedings of the Third Symposium on the Cerro Prieto Geothermal Field, Mexico, 1981.
[27] S. Vonder Haar and J. H. Howard, "Intersecting faults and sandstone stratigraphy at the cerro prieto geothermal field," Geothermics, vol. 10, no. 3-4, pp. 145-167, 1981.

[28] A. Manon, E. Mazor, M. Jimenez, A. Sanchez, J. Fausto, and C. Zenizo, "Extensive geochemical studies in the geothermal field of Cerro Prieto, Mexico," Tech. Rep. LBL-7019, 1977.

[29] E. Mazor and A. Mañon M., "Geochemical tracing in producing geothermal fields: A case study at Cerro Prieto," Geothermics, vol. 8, no. 3-4, pp. 231-240, 1979.

[30] A. H. Truesdell, R. O. Rye, F. J. Pearson Jr. et al., "Preliminary isotopic studies of fluids from the Cerro Prieto geothermal field," Geothermics, vol. 8, no. 3-4, pp. 223-229, 1979.

[31] A. H. Truesdell, J. M. Thompson, T. B. Coplen, N. L. Nehring, and C. J. Janik, "The origin of the Cerro Prieto geothermal brine," Geothermics, vol. 10, no. 3-4, pp. 225-238, 1981.

[32] H. A. Truesdell, M. J. Lippmann, and H. Gutiérrez-Puente, "Evolution of the Cerro Prieto Reservoirs under exploitation," in Proceedings of the Anual Meeting of the Geothermal Resources Council, pp. 1-7, Burlingame, Calif, USA, 1997.

[33] M. J. Lippmann, A. H. Truesdell, and K. Pruess, "The control of fault $\mathrm{H}$ on the hydrology of the Cerro Prieto III Area," in Proceedings of the Twenty-fifth Workshop on Geothermal Reservoir Engineering Standford University, Standford, Calif, USA, 2000.

[34] T. B. Coplen, "Origin of geothermal waters in the Imperial Valley of southern California. Cooperative Investigation of Geothermal Resources in the Imperial Valley and their Potential Value for Desaltine of Water and other purposes," R. W. Rex, Ed., Rwerslde Report IGPP-UCR-72-33, pp. E1-E31, University of California, 1972.

[35] P. Birkle, E. P. Marín, D. L. Pinti, and M. C. Castro, "Origin and evolution of geothermal fluids from Las Tres Vírgenes and Cerro Prieto fields, Mexico - Co-genetic volcanic activity and paleoclimatic constraints," Applied Geochemistry, vol. 65, pp. 36-53, 2016.

[36] D. Nieva and R. Nieva, "Developments in geothermal energy in Mexico-part twelve. A cationic geothermometer for prospecting of geothermal resources," Heat Recovery Systems and CHP, vol. 7, no. 3, pp. 243-258, 1987.

[37] S. P. Verma and E. Santoyo, "New improved equations for $\mathrm{Na} / \mathrm{K}, \mathrm{Na} / \mathrm{Li}$ and $\mathrm{SiO} 2$ geothermometers by outlier detection and rejection," Journal of Volcanology and Geothermal Research, vol. 79, no. 1-2, pp. 9-23, 1997.

[38] AWWA, APHA, and WWF, Standard methods for the Examination of Water and Wastewater, American Public health Association, The American Water Works Association, Association Water Environment Federation, Washington, D.C., USA, 2005.

[39] A. B. Carpenter, "Origin and chemical evolution of brines in sedimentary basins Oklahoma," Geological Survey Circular, vol. 79, pp. 78-88, 1978.

[40] M. L. Davisson and R. E. Criss, "Na-Ca-Cl relations in basinal fluids," Geochimica et Cosmochimica Acta, vol. 60, no. 15, pp. 2743-2752, 1996.

[41] E. R. Olson, "Oxygen and Carbon isotopes studies of calcite from the Cerro Prieto Geothermal Field," in Proceedings of the First Symposium on the Cerro Prieto Geothermal Field, Baja California, Mexico, 1978.

[42] Hiriart Le Bert, Evaluación de la Energía Geotérmica en México Informe para el Banco Interamericano de Desarrollo y la Comisión Reguladora de Energía http://www.cre.gob.mx/ documento/2026.pdf, 2011. 
[43] W. J. Harrison and L. L. Summa, "Paleohydrology of the Gulf of Mexico basin," American Journal of Science, vol. 291, no. 2, pp. 109-176, 1991.

[44] E. D. Pittman and R. E. Larese, "Compaction of lithic sands: experimental results and applications," The American Association of Petroleum Geologists Bulletin, vol. 75, pp. 1279-1299, 1991.

[45] J. Gluyas and C. A. Cade, "Prediction of porosity compacted sands," in Reservoir Quality Prediction in Sandstones and Carbonates, A. Kupecz, Gluyas J., and S. Bloch, Eds., vol. 69, pp. 19-28, AAPG, Memoir, 1997.

[46] S. N. Ehrenberg and P. H. Nadeau, "Sandstone vs. carbonate petroleum reservoirs: A global perspective on porosity-depth and porosity-permeability relationships," AAPG Bulletin, vol. 89, no. 4, pp. 435-445, 2005.

[47] R. M. Prol-Ledesma, C. Arango-Galván, and M.-A. Torres-Vera, "Rigorous analysis of available data from cerro prieto and las tres virgenes geothermal fields with calculations for expanded electricity generation," Natural Resources Research, vol. 25, no. 4, pp. 445-458, 2016.

[48] J. S. Hanor, "Origins of saline fluids in sedimentary basins," in Geofluids: Origin, Migration and Evolution of Fluids in Sedimentary Basins, J. Parnell, Ed., pp. 151-174, Geological Society of London, 1994.

[49] A. W. Hounslow, Water Quality Data, Analysis and Interpretation, Taylor \& Francis Group, 1995.

[50] J. N. Valette-Silver, J. M. Thompson, and J. W. Ball, "Relationship between water chemistry and sediment mineralogy in the Cerro Prieto Geothermal Field: A preliminary report," Geothermal Energy, pp. 263-273, 1981.

[51] K. H. Wolf and G. V. Chilingarian, "Chapter 1 Introduction," Developments in Sedimentology, vol. 51, no. C, pp. 1-17, 1994.

[52] P. Kaur, N. Chaudhri, A. W. Hofmann et al., "Two-stage, extreme albitization of A-type granites from Rajasthan, NW India," Journal of Petrology, vol. 53, article egs003, no. 5, pp. 919948, 2012.

[53] I. Demir and B. Seyler, "Chemical composition and geologic history of saline waters in Aux Vases and Cypress Formations, Illinois Basin," Aquatic Geochemistry, vol. 5, no. 3, pp. 281-311, 1999.

[54] G. V. Chilingarian, T. F. Donaldson, and T. F. Yen, "Subsidence due to fluid withdrawal," in Developments in Petroleum Science, vol. 519, 41 Elsevier Sciences, 1995.

[55] A. Garcia, F. Ascencio, G. Espinosa, E. Santoyo, H. Gutierrez, and V. Arellano, "Numerical modeling of high temperatura deel Wells in the Cerro Prieto geotermal fiels, Mexico," Geofisica Internacional, vol. 38, pp. 251-260, 1999.

[56] M. J. Lippmann, A. H. Truesdell, and H. Gutierrez-Puente, "What will a $6 \mathrm{~km}$ deep well at Cerro Prieto find," in Proceedings of the twenty-first Workshop on Geothermal Reservoir Engineering, Stanford University, 1997, https://pangea.stanford .edu/ERE/pdf/IGAstandard/SGW/1997/Lippmann.pdf.

[57] M. J. Osborne and R. E. Swarbrick, "Mechanisms for generating overpressure in sedimentary basins: A reevaluation," $A A P G$ Bulletin, vol. 81, no. 6, pp. 1023-1041, 1997.

[58] A. M. Stueber and L. M. Walter, "Origin and chemical evolution of formation waters from Silurian-Devonian strata in the Illinois basin, USA," Geochimica et Cosmochimica Acta, vol. 55, no. 1, pp. 309-325, 1991.

[59] N. H. Mondol, K. Bjørlykke, J. Jahren, and K. Høeg, "Experimental mechanical compaction of clay mineral aggregatesChanges in physical properties of mudstones during burial," Marine and Petroleum Geology, vol. 24, no. 5, pp. 289-311, 2007.
[60] R. O. Fournier and J. J. Rowe, "Estimation of underground temperatures from the silica content of water from hot springs and wet-steam wells," American Journal of Science, vol. 264, no. 9, pp. 685-697, 1966.

[61] R. Sonney, Groundwater flow, heat and mass transport in geothermal systems of a Central Alpine Massif. The cases of Lavey-les Bains, Saint-Gervais-les-Bains and Val d'Illiez. Geochemistry. Université de Neuchatel, 2010.

[62] F. D’Amore and S. Arnórsson, "Isotopic and chemical techniques in geothermal exploration, development and use. Sampling methods, data handling, interpretation," in Geothermometry, S. Arnórsson, Ed., pp. 152-199, International Atomic Energy Agency, Vienna, Austria, 2000. 

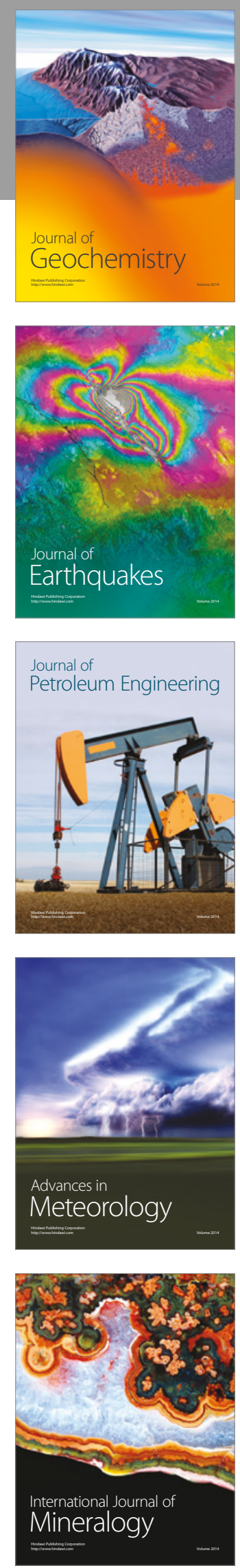
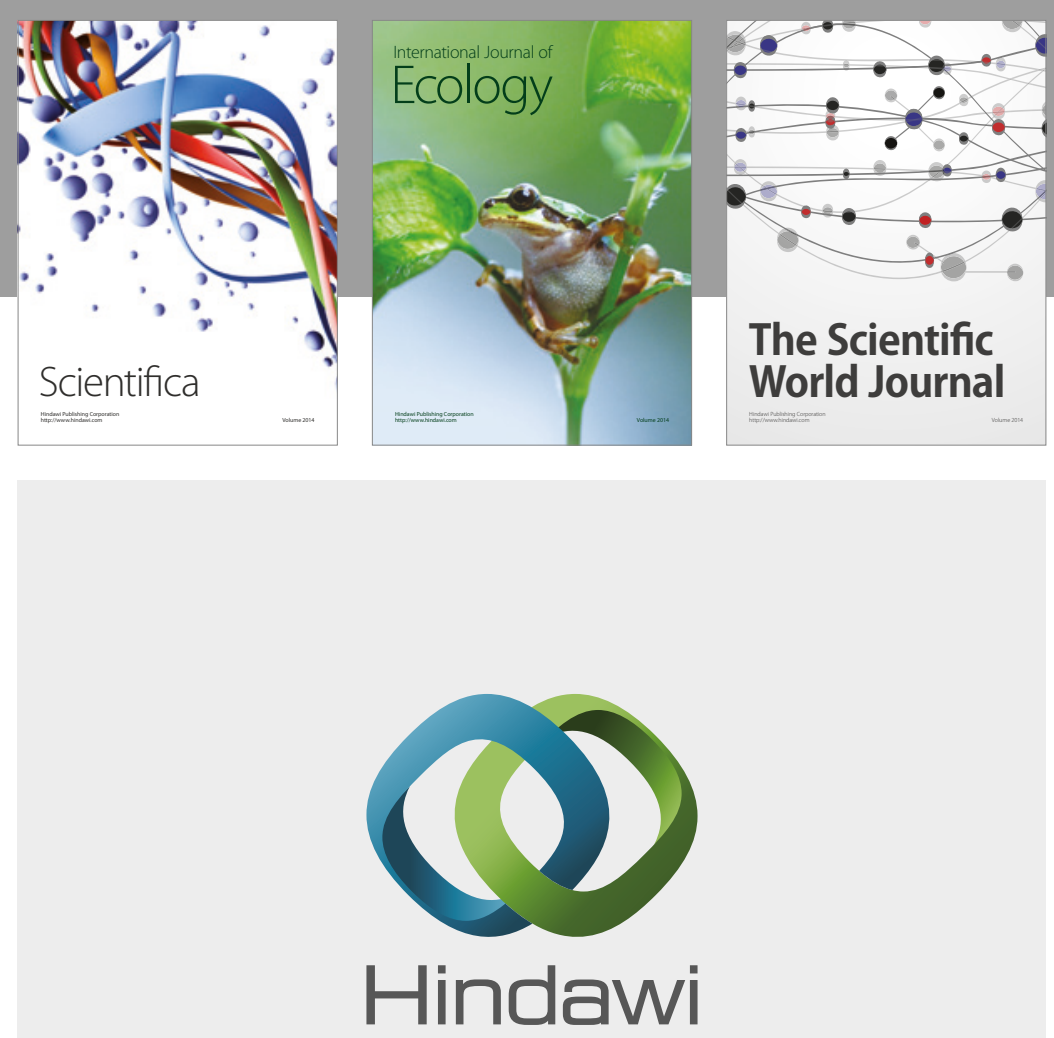

Submit your manuscripts at

https://www.hindawi.com
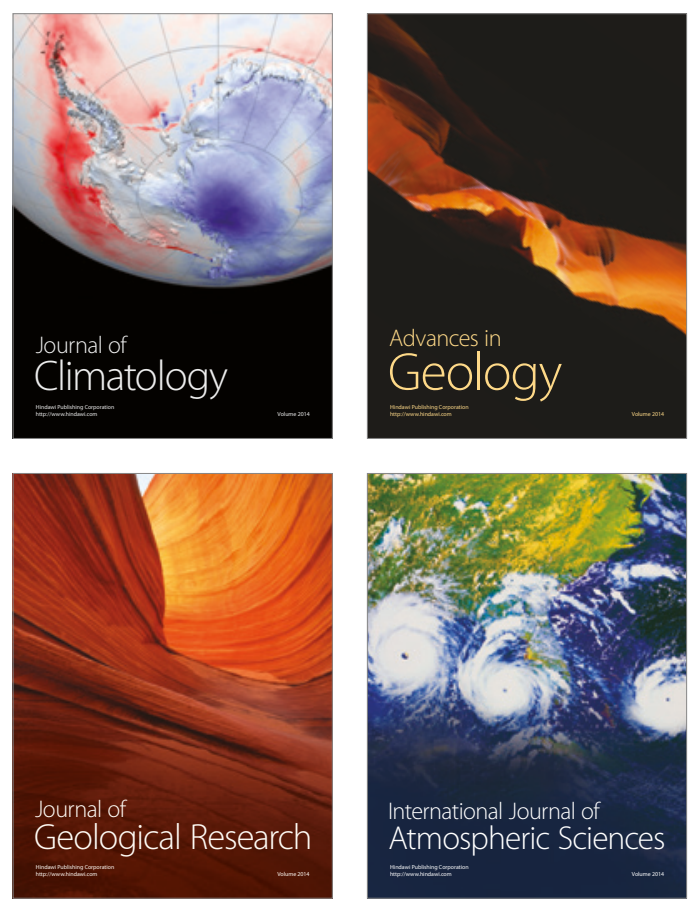

The Scientific

World Journal
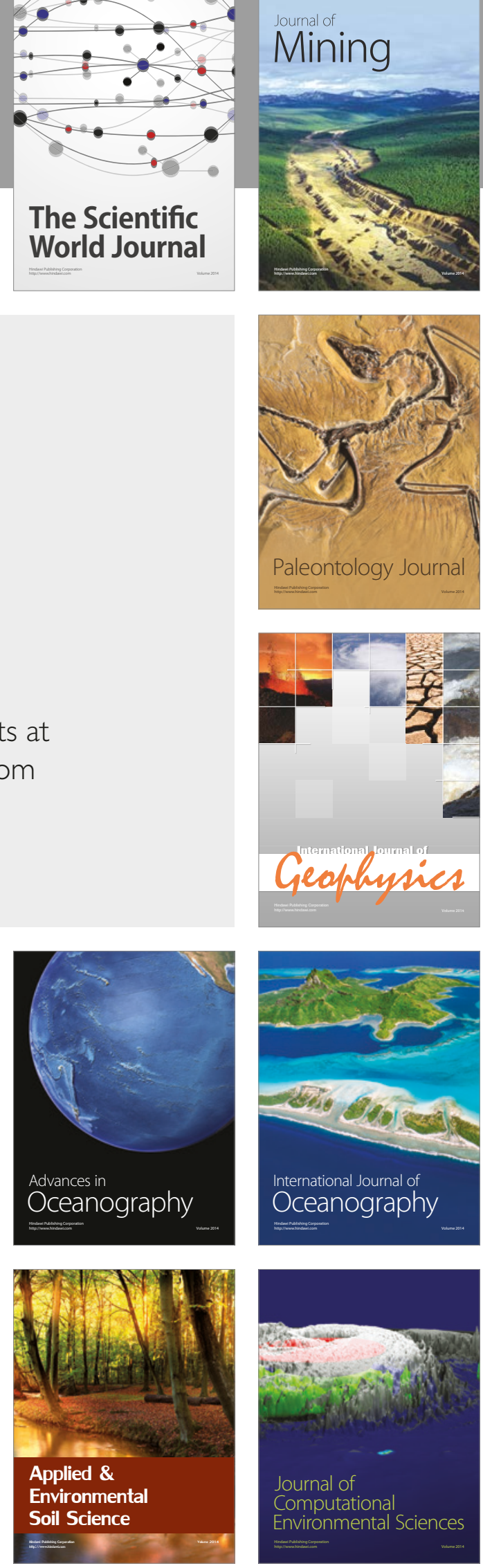